\title{
HOOFDARTIKELEN
}

\section{Schikken in het nieuwe ontslagrecht: bedenk eer ge begint}

\author{
L.G. Verburg
}

\section{Inleiding}

Op 14 juni 2014 heeft de Wet werk en zekerheid (Wwz) het Staatsblad gehaald. ${ }^{1}$ De Wwz introduceert in artikel 670b lid $2^{2}$ voor de werknemer de mogelijkheid om een door deze werknemer met zijn werkgever aangegane overeenkomst tot beëindiging van de arbeidsovereenkomst binnen veertien dagen na de datum van de totstandkoming van de overeenkomst te ontbinden door een schriftelijke verklaring. ${ }^{3}$ De werknemer mag dit doen zonder opgaaf van redenen. Een soortgelijk 'bedenkrecht' heeft de werknemer die schriftelijk heeft ingestemd met een opzegging van de arbeidsovereenkomst door de werkgever (artikel 670a lid 2 en 5 en artikel 671 lid 1 en 2). ${ }^{4}$ Deze werknemer kan zijn instemming herroepen. Men spreekt in beide situaties over de 'bedenktermijn'.

1 Wet van 14 juni 2014 tot wijziging van verschillende wetten in verband met de hervorming van het ontslagrecht, wijziging van de rechtspositie van flexwerkers en wijziging van verschillende wetten in verband met het aanpassen van de Werkloosheidswet, het verruimen van de openstelling van de Wet inkomensvoorziening oudere werklozen en de beperking van de toegang tot de Wet inkomensvoorziening oudere en gedeeltelijk arbeidsongeschikte werkloze werknemers (Wet werk en zekerheid), Stb. 2014, 216.

2 Bepalingen uit de Wwz duid ik aan op de in de tekst aangegeven wijze (het voorbeeld van artikel 670b lid 2, dus zonder '7:' en zonder 'BW'); wetsartikelen die afkomstig zijn uit titel 10 van Boek 7 BW, zoals deze titel thans luidt, duid ik aan op de gebruikelijke wijze (bijvoorbeeld: artikel 7:611 BW). Een verwijzing naar artikel 7:682 BW gaat derhalve over het herstel van het dienstverband als variant op het thema van het kennelijk onredelijk ontslag naar huidig recht, een verwijzing naar artikel 682 heeft betrekking op het herstel van het dienstverband in de zin van de Wwz.

3 Op grond van de ontvangsttheorie van artikel 3:37 BW geldt bij een later dispuut over de vraag of werd herroepen, dat het aan de werknemer is te stellen en indien nodig te bewijzen dat hij de herroeping op tijd heeft gedaan. Met andere woorden: dat hij tijdig heeft verzonden en dat deze binnen de termijn van veertien dagen door de werkgever is ontvangen. Aldus Kamerstukken II 2013/14, 33818, 3, p. 103.

4 De introductie van de figuur van de opzegging met instemming heeft een technische achtergrond. Deze figuur 'realiseert' in de visie van de regering de preventieve toets. Zie Kamerstukken I 2013/14, 33818, C, p. 80. Vergelijk ook Kamerstukken II 2013/14, 33818, 4, p. 55. Er is de nodige discussie geweest over nut en noodzaak van deze complicerende aanpak en de Vereniging Arbeidsrecht Advocaten Nederland (VAAN) heeft op 2 juni 2014, kort voor het plenaire debat in de Eerste Kamer, nog een voorstel gedaan voor een vereenvoudigd ontslagrecht zonder de figuur van de opzegging met instemming. De regering heeft voet bij stuk gehouden. Ik laat dit discussiepunt hier verder rusten. 
De discussie over de bedenktermijn heeft in de wetsgeschiedenis geen goed afgewogen plek gekregen. Het gevonden resultaat is niet de vrucht van overleg met en raadpleging van de praktijk. De diverse relevante passages in de wetsgeschiedenis zijn niet volledig doordacht en sluiten, zoals hieronder zal blijken, niet nauwkeurig op elkaar aan. ${ }^{5}$

Deze bijdrage behandelt enige voetangels en klemmen die de bedenktermijn legt op de weg naar een schikking van een ontslag.

\section{De Wwz en het aandeel ontslagen met wederzijds goedvinden}

De regering stelt te verwachten dat de Wwz leidt tot een toename van het aandeel ontslagen met wederzijds goedvinden, ${ }^{6}$ maar plaatst met een bedenktermijn van maar liefst veertien dagen tegelijkertijd een stevig obstakel op de weg. De regering maakt niet duidelijk hoe het aandeel ontslagen met wederzijds goedvinden thans ligt. De passage blijft daarom wat in het luchtledige hangen. Het schikken van arbeidsgeschillen is sinds jaar en dag dagelijkse arbeid in het huis van de arbeidsovereenkomst en ik vermoed dat het aandeel geschikte ontslagzaken al enorm hoog ligt. Er zijn meer drijfveren voor het sluiten van compromissen dan de richtsnoeren van het (ontslag)recht. Ten aanzien van de mogelijke oorzaken van een toename van deals als gevolg van de Wwz spelen voorts nogal ongelijksoortige argumenten. De wettelijke normering van de ontslagvergoeding via de regeling van de transitievergoeding verschaft ongetwijfeld een zekere duidelijkheid, maar de nieuwe benadering van de ontslaggronden (ik doel op de semigesloten 'per grond'-benadering in plaats van de huidige holistische benadering van een ontslagdossier ${ }^{7}$ ) maakt een vast dienstverband nog vaster en dat zal weer aanleiding

5 Ik heb er gezien de complexiteit van de materie meer begrip voor dan het voorbeeld van niet consistent zijn dat is te vinden in de passage in de MvA waarin de regering aangeeft dat het bij een zo belangrijk onderwerp als de ontslagbescherming van werknemers tot de verantwoordelijkheid van de wetgever behoort om in wet- en regelgeving concreet invulling te geven aan zaken en niet te volstaan met open normen zoals thans in het BW. Zie Kamerstukken I 2013/14, 33818, C, p. 89. De Wwz is welhaast geplaveid met open normen.

6 Kamerstukken I 2013/14, 33818, C, p. 98.

7 In het huidige systeem kan de kantonrechter de arbeidsovereenkomst ontbinden via de open norm van de gewichtige reden en is het mogelijk in een zwakker dossier toch tot ontbinding over te gaan, waarbij de ontslagvergoeding naar billijkheid naargelang de zwakte valt bij te plussen. Deze 'smeerolie' valt in de Wwz in beginsel volledig weg. De rechter moet net als het UWV per grond oordelen en mag daarbij geen rekening houden met eventuele andere gronden en overwegingen. De rechter moet dus ziende blind oordelen. Over het verlies van de huidige '685procedure' als smeerolie in en van het systeem van het ontslagrecht stelt de wetgever slechts dat de essentie van het ontslagrecht is dat de werknemer zich beschermd weet tegen ontslag zonder redelijke grond en doet met de volgende zin de (looien) deur dicht: 'De rechter kan niet ontbinden als onvoldoende blijkt dat er een redelijke grond voor ontslag is.' Zie Kamerstukken I 2013/14, 33818, E, p. 9. Idem eerder Kamerstukken I 2013/14, 33818, C, p. 87. In het plenaire debat met de Tweede Kamer bevestigde de minister van SZW overigens met zoveel woorden dat een versoepeling van het ontslagrecht geen doel van de Wwz is. Wat hij onvermeld liet (de Tweede Kamer legde hem ook geen strobreed in de weg), is dat vast vaster wordt. 
geven tot deals met hogere vergoedingen. ${ }^{8}$ Ik doel daarbij op de bedragen die zijn gemoeid met het afkopen van het risico van mislukte pogingen via het Uitvoeringsinstituut werknemersverzekeringen (UWV) of de kantonrechter om tot een einde van de relatie te komen. Ik heb dus niet het 'muizengaatje' van de billijke vergoeding op het oog, maar de kop op de transitievergoeding die de werknemer over de streep trekt te berusten in een einde van zijn dienstverband. Die deals komen er alleen maar als het bedrijfsleven bereid is die hogere vergoedingen te betalen. Het antwoord is niet moeilijk te vinden: het hangt af van de omstandigheden van het geval. Het is nog de vraag of door de bank genomen de transitievergoeding bij onderhandelingen de benchmark zal zijn of de ondergrens.

Ik zie geen aanleiding voor de veronderstelling dat het percentage van de deals zal toenemen. ${ }^{9}$ De bedenktermijn doet in ieder geval een zekere afbreuk aan de schikkingsbereidheid van werkgevers voor zover deze partijen tegenover betaling van een hoger bedrag niet direct zekerheid kunnen kopen om er dan ook definitief van af te zijn. Een dergelijke 'emotie' speelt nu eenmaal vaak een rol. Ik houd het er hier op dat de passage over een toename van het aandeel ontslagen met wederzijds goedvinden het belang van het thema voor de praktijk toont.

\section{Doel, techniek en effecten van de bedenktermijn}

De bedenktermijn biedt de werknemer extra bescherming in verband met het grote belang voor de werknemer bij een arbeidsovereenkomst en gelet op het aan het arbeidsrecht ten grondslag liggende beginsel van de ongelijkheidscompensatie. ${ }^{10}$ De nota naar aanleiding van het verslag van 3 februari 2014 stelt dat de bedenktermijn in het leven is geroepen om te voorkomen dat een werknemer al dan niet onder psychische druk van de werkgever, in een emotionele toestand, instemt met een opzegging of deal, terwijl hij onvoldoende heeft kunnen overzien welke gevolgen de beëindiging voor hem heeft. De werknemer moet een reële

8 De door de VAAN geuite zorg dat vast vaster wordt, pareert de wetgever met de volgende zin: 'Een toename dan wel afname van ontbindingsverzoeken zal mede afhankelijk zijn van hetgeen aan de rechter wordt voorgelegd die vervolgens zal moeten oordelen of een werknemer terecht of onterecht voor ontslag wordt voorgedragen.' Zie Kamerstukken I 2013/14, 33818, E, p. 9. Men herkent in deze passage van het type dooddoener de techniek van het wegschrijven. Ik noteer wel dat de MvA geen enkele afstand neemt van de gedachte van de VAAN dat vast vaster wordt. Zie de desbetreffende vraag en het antwoord van de minister in Kamerstukken I 2013/14, 33818, C, p. 87.

9 De transitievergoeding werkt tot het moment dat de werkgever toestemming vraagt c.q. ontbinding verzoekt van de zijde van de werknemer, eerder vertragingstactieken in de hand. Hij heeft immers niets te verliezen, stilzitten loont dus tot de start van de procedure bij het UWV/de kantonrechter. Dit laatste vloeit mede voort uit de verplichting voor de ontbindingsrechter om in beginsel bij ontbinding de geldende opzegtermijn in de te bepalen einddatum van het dienstverband te verdisconteren op de wijze als aangegeven in artikel $671 \mathrm{~b}$ lid 8 onderdeel a. De ontbindingsrechter kan de einddatum alleen maar bepalen op een eerder tijdstip indien de ontbinding van de arbeidsovereenkomst het gevolg is van ernstig verwijtbaar handelen of nalaten van de werknemer (artikel 671b lid 8 onderdeel b). Dit laatste zal gezien de hoogte van de meetlat bij een op aannemelijkheid gestoelde verzoekschriftprocedure (heel) weinig voorkomen. 
mogelijkheid hebben juridisch advies in te winnen. ${ }^{11}$ De wetgever refereert taalkundig correct aan een ontbinding van de beëindigingsovereenkomst en aan een herroeping van de instemming met de opzegging. In het eerste geval treft de actie een wederkerige overeenkomst, in het tweede geval maakt de werknemer een eigen rechtshandeling ongedaan. Het inroepen van de bedenktermijn bewerkstelligt in feite een buitengerechtelijke vernietiging van het resultaat van de overeenstemming.

Het rechtsgevolg van de herroeping van de instemming met een opzegging is overigens niet gelijk aan dat van de ontbinding van de beëindigingsovereenkomst. De herroeping van de instemming met een opzegging heeft terugwerkende kracht. De ontbinding van de beëindigingsovereenkomst heeft op zich geen terugwerkende kracht.

Artikel 671 lid 4 legt voor de herroeping van de instemming met de opzegging expliciet vast dat voor zover de instemming vereist was voor een rechtsgeldige opzegging, de opzegging geacht wordt niet te hebben plaatsgevonden. Dit laatste beoogt te voorkomen dat de werknemer een gang naar de rechter moet maken om de opzegging te laten vernietigen wegens het ontbreken van instemming. ${ }^{12}$ Het 'voor zover' strookt met de gedachte dat het herroepen van een aanvankelijke instemming van de werknemer met een opzegging door de werkgever wegens een dringende reden of tijdens de proeftijd de desbetreffende opzegging natuurlijk niet onderuit behoort te halen. De nota van wijziging van 3 februari 2014 maakte dit duidelijk met de passage dat het rechtsgevolg van het herroepen slechts intreedt als de instemming ook daadwerkelijk nodig was om rechtsgeldig te kunnen opzeggen. Dit voorkomt dat naar de letter van de wet de mogelijkheid zou bestaan onverplicht in te stemmen met bijvoorbeeld een ontslag tijdens de proeftijd, om deze instemming vervolgens te herroepen met voornoemd rechtsgevolg. ${ }^{13}$

De ontbinding van de beëindigingsovereenkomst heeft in mijn visie geen terugwerkende kracht. De memorie van toelichting (MvT) wekt in de bespreking van het thema in het algemeen deel van de MvT de indruk dat dit wel het geval is. Op bladzijde 27 geeft de MvT aan dat bij de herroeping van de instemming met een opzegging de opzegging geacht wordt niet te hebben plaatsgevonden, en vervolgt de tekst met de constatering dat dit ook geldt voor de situatie waarin ter zake van de arbeidsovereenkomst een zogenoemde beëindigingsovereenkomst is gesloten. Men kan dit lezen als een bevestiging van de gedachte dat de ontbinding tot effect heeft dat de beëindigingsovereenkomst geacht wordt niet te hebben plaatsgevonden. Dat impliceert dan dat de ontbinding terugwerkende kracht heeft. De passage op bladzijde 27 van de MvT strookt evenwel niet met het feit dat de MvT in het artikelsgewijs commentaar expliciet aansluiting zoekt bij de regeling van de buitengerechtelijke ontbinding in Boek 6 van het Burgerlijk Wetboek (BW). Op bladzijde 103 van de MvT staat dat de werknemer de beëindigingsovereenkomst

11 Kamerstukken II 2013/14, 33818, 7, p. 56.

12 Kamerstukken II 2013/14, 33818, 3, p. 27, Kamerstukken II 2013/14, 33818, 4, p. 64, Kamerstukken II 2013/14, 33818, 7, p. 55, Kamerstukken I 2013/14, 33818, C, p. 80. 
buitengerechtelijk kan ontbinden onder verwijzing naar artikel 6:265 BW en verder. Dat 'en verder' geeft uitsluitsel over het rechtsgevolg van de ontbinding. Artikel 6:269 BW legt vast dat de ontbinding geen terugwerkende kracht heeft en artikel 6:271 BW bepaalt dat de ontbinding de partijen bevrijdt van de daardoor getroffen verbintenissen. Voor zover deze reeds zijn nagekomen, blijft de rechtsgrond van deze nakoming in stand, maar ontstaat voor partijen een verbintenis tot ongedaanmaking van de reeds door hen ontvangen prestaties.

In de situatie dat de arbeidsovereenkomst op grond van de inhoud van de beëindigingsovereenkomst reeds tot een einde is gekomen voordat de werknemer gebruikmaakte van zijn bedenkrecht, noopt deze verbintenis tot ongedaanmaking (van de verbintenissen die voortvloeiden uit de door de ontbinding getroffen beëindigingsovereenkomst) tot een herstel van het dienstverband met terugwerkende kracht tot het moment waarop de arbeidsovereenkomst krachtens de beëindigingsovereenkomst een einde nam. In het laatste geval zal de werkgever dus loon en dergelijke moeten betalen vanaf de hersteldatum. ${ }^{14}$ Het feit dat de werknemer enkele dagen niet zal hebben gewerkt, behoort hier geen tegenargument op te leveren. De werkgever behoort op de hoogte te zijn geweest van de wettelijke regeling en heeft dus willens en wetens het risico aanvaard dat na het inroepen van het bedenkrecht met terugwerkende kracht loon en dergelijke moeten worden betaald zonder dat hier arbeid tegenover stond. Het lijkt me zonder andersluidend richtsnoer van de wetgever dat het niet verrichten van arbeid in dit geval in beginsel niet voor rekening van de werknemer komt (ik heb hierbij het oog op het bepaalde in artikel 628 lid 1). Men kan de gedachte van 'geen arbeid, dan ook geen loon' in deze situatie voorts beschouwen als een beletsel voor de werknemer om van het bedenkrecht gebruik te maken. ${ }^{15}$

Ik laat het (aparte) thema van deals rond een door een werkgever gegeven ontslag op staande voet buiten nadere beschouwing, maar voorzie wel dat een dergelijke deal steevast een voorwaardelijk karakter zal moeten hebben. De bedoelde voorwaarde is dat geen gebruik is gemaakt van het bedenkrecht. Ik noteer voorts dat een deal rond een nog niet gegeven ontslag op staande voet in die zin een gevaarlijke kant kent dat de werknemer tegen het einde van de bedenktermijn de deal kan ontbinden en de werkgever dan niet meer alsnog rechtsgeldig op staande voet zal kunnen ontslaan. Er zal immers niet meer zijn voldaan aan het vereiste van onverwijldheid. Voorts zullen werkgevers bij een deal rond een (al of niet gegeven) ontslag op staande voet zolang de periode van de bedenktermijn nog voort-

14 De afspraak dat geen loon verschuldigd is over de niet gewerkte dagen bij het inroepen van de bedenktermijn in een deal die betrekking heeft op een arbeidsovereenkomst die nog geen zes maanden heeft geduurd, is op grond van artikel 628 lid 5 weliswaar geldig, maar wordt door de ontbinding van de beëindigingsovereenkomst net zo hard onderuit gehaald als de andere afspraken in deze overeenkomst. Een eventueel over de desbetreffende periode al ontvangen WW-uitkering (zo'n vaart neemt dat overigens niet, het zal dus niet of nauwelijks spelen) moet als onverschuldigd uitgekeerd worden terugbetaald.

15 Het zal in beginsel niet verstandig zijn in een deal af te spreken dat de arbeidsovereenkomst binnen de periode van de bedenktermijn tot een einde komt en het is al helemaal onverstandig af te spreken dat betaling van de ontslagvergoeding plaatsvindt binnen die termijn van veertien dagen. 
duurt alle acties tot behoud van c.q. tot verkrijging van relevante gegevens moeten continueren, terwijl de bedenktermijn werknemers mogelijkheden biedt dit wapen in te zetten om te bewerkstelligen dat ruimte ontstaat voor handelingen (het laten verdwijnen van bewijsmateriaal) die het hard maken van de dringende reden voor de werkgever juist lastiger maken. De wetsgeschiedenis gaat aan deze materie geheel voorbij.

Pikant is tot slot dat de wetgever de buitengerechtelijke vernietiging van de opzegging van de arbeidsovereenkomst niet langer toelaat in de Wwz vanwege wensen op het punt van een vereenvoudiging en versnelling van het ontslagrecht, en zich in het wetgevingsproces met verve heeft verzet tegen suggesties dit standpunt alsnog te verlaten. ${ }^{16}$ Met even groot gemak introduceert de wetgever welbeschouwd de buitengerechtelijke vernietiging van een instemming met een opzegging respectievelijk een beëindigingsovereenkomst. Het zonder blikken of blozen verkondigen van redelijkerwijs als tegengesteld op te vatten standpunten is opmerkelijk. De bedenktermijn vereenvoudigt en versnelt het ontslagrecht allerminst. Het onderscheid tussen enerzijds een buitengerechtelijke vernietiging (van de opzegging) en anderzijds een buitengerechtelijke ontbinding (van een beëindigingsovereenkomst als bedoeld in artikel 670b lid 2) of een buitengerechtelijke herroeping (van de instemming met een opzegging als bedoeld in artikel 670a lid 5/artikel 671 lid 2) ziet vooral op het feit dat de vernietiging van een opzegging betrekking heeft op een rechtshandeling van de wederpartij, terwijl de bedenktermijn het recht geeft 'op de eigen schreden terug te keren'. Artikel 671 lid 4 vervolmaakt evenwel de gelijkenis met een buitengerechtelijke vernietiging van de opzegging. Ik ervaar althans geen verschil tussen een buitengerechtelijke vernietiging van de opzegging en de wettelijke bepaling dat bij een herroeping de opzegging wordt geacht niet te hebben plaatsgevonden.

\section{Sagels interventie betreffende de bedenktermijn en de reactie van de regering}

Sagel heeft in het reeds in januari 2014 ter beschikking gekomen maartnummer van het Tijdschrift Recht en Arbeid (TRA) aandacht gevraagd voor de bedenktermijn. ${ }^{17}$ Zijn bijdrage heeft bij de regering op een aantal punten (terecht) gehoor gevonden. In de nota van wijziging van 3 februari 2014 heeft de regering op de volgende door Sagel besproken aspecten het wetsvoorstel aangepast. ${ }^{18} \mathrm{Ik}$ volsta met een korte opsomming; mijn betoog concentreert zich op de nu nog bestaande voetangels en klemmen en niet op wat reeds een passende bedding kreeg. De beëindigingsovereenkomst moet schriftelijk worden aangegaan. Ook de instemming met een opzegging moet schriftelijk geschieden. De werkgever is verplicht de werknemer schriftelijk te wijzen op het bestaan van de bedenktermijn en de regering heeft een regeling getroffen voor de situatie dat de werknemer voorzitter van de Eerste Kamer van 10 juni 2014, p. 3.

17 S.F. Sagel, De bedenkelijke bedenktermijnen in Wetsvoorstel Werk en Zekerheid, TRA 2014/27.

18 Zie de bespreking van zijn bijdrage in de MvA in Kamerstukken I 2013/14, 33818, C, p. 47-49. 
door de werkgever niet op de hoogte is gebracht van het bestaan van de bedenktermijn. ${ }^{19}$ De wetgever heeft bovendien, om misbruik te voorkomen, bepaald dat een werknemer de bedenktermijn niet nogmaals toekomt als er zich tussen dezelfde partijen binnen zes maanden een vergelijkbare situatie voordoet (de antistapelingsbepaling). Deze laatste bepaling is te vinden in artikel 670b lid 4/ artikel 671 lid 5 en voorziet erin dat men zich per periode van zes maanden slechts eenmaal mag bedenken. Dit laatste voorkomt ongelimiteerd terugkomen op een in- of overeenstemming. Dat zou de deal minder aantrekkelijk maken. Een tweede keer is ongelijkheidscompensatie in de visie van de regering ook niet aan de orde, nu verwacht mag worden dat de werknemer na de eerste keer voldoende heeft nagedacht en juridische bijstand heeft ingeroepen. ${ }^{20}$ De wetsgeschiedenis wijdt geen woord aan de mogelijkheid deze antistapelingsbepaling in te zetten in het schaakspel der onderhandelingen over een vertrekregeling. Ik kom daar later op terug.

Op één belangrijk onderdeel van de bijdrage van Sagel is de regering niet ingegaan. Sagel stelde dat de bedenktermijn niet kan worden weggecontracteerd door een pro-forma-ontbinding onderdeel te laten zijn van de tussen hen gesloten beëindigingsregeling. Hij doelde op de tekst op bladzijde 103 van de MvT aangaande de 'deal op de gang'. Sagel heeft gelijk met de gedachte dat men de bedenktermijn niet kan wegcontracteren door het afspreken van een pro-formaontbinding. Dat stelt de MvT op bladzijde 103 ook niet. De MvT maakt een onderscheid tussen de beëindigingsovereenkomst en de overeenkomst over wat de MvT aanduidt met de 'losse eindjes'. De beëindigingsovereenkomst zelf is uiteraard onderworpen aan een bedenktermijn. De tekst van de MvT op bladzijde 103 heeft geen betrekking op de beëindigingsovereenkomst. De MvT heeft het oog op de aparte overeenkomst over de losse eindjes. Die overeenkomst is niet onderworpen aan een bedenktermijn. Ik constateer ook dat na en naar aanleiding van de bijdrage van Sagel de regering te dien aanzien niet op enige schrede is teruggekeerd. De wetgever heeft derhalve klip en klaar besloten de overeenkomst betreffende de als 'losse eindjes' aangeduide zaken, hoe belangrijk deze zaken ook zijn, ${ }^{21}$ los te koppelen van de beëindigingsovereenkomst en het thema van de bedenktermijn. De rechter zal zich hieraan moeten houden, de wetsgeschiedenis biedt geen speelruimte. Mocht later uit evaluaties van de Wwz blijken dat het anders moet, dan is de wetgever aan zet. De kanttekeningen die Sagel bij een en ander plaatst zijn op zichzelf niet onbegrijpelijk, maar stuiten af op de wetsgeschiedenis. Met 'niet onbegrijpelijk' bedoel ik ook dat zeer wel denkbaar

19 De sanctie op het onvermeld laten van de bedenktermijn is een verlenging van de termijn van veertien dagen naar drie weken (artikel 670b lid 3 respectievelijk artikel 671 lid 3). In eerste instantie werd gedacht aan een maand. Het door de Tweede Kamer in februari 2014 aangenomen amendement nr. 34 bracht de sanctie ten aanzien van het niet mededelen van de bedenktermijn van een maand in plaats van veertien dagen terug naar een termijn van drie weken.

20 Kamerstukken II 2013/14, 33818, 7, p. 57 en Kamerstukken II 2013/14, 33818, 8, p. 17.

21 Het zou natuurlijk bepaald onverstandig zijn een kwijtingsclausule als 'eindje' wat losjes op te vatten. Dat doet de MvT op p. 103 ook niet. De MvT legt slechts vast dat zo'n clausule voor wat betreft de toepassing van de bedenktermijn in de aangegeven situatie losstaat van de beëindigingsovereenkomst. 
zou zijn geweest dat zijn commentaar tot een verandering van de opzet van het systeem van de bedenktermijn had geleid. Dat is niet het geval geweest. Ik vermoed dat dit zeer bewust is geschied, uit een terechte zorg dat als men de bedenktermijn ook laat gelden voor de overeenkomst over de 'losse eindjes', dit het einde van de dagelijkse gang van zaken rond de deals op de gangen van het gerechtsgebouw had ingeluid. Ik deel die zorg van de regering. Sterker nog, het lijkt me evident dat er veel minder schikkingen tijdens de mondelinge behandeling van een ontbindingsverzoek tot stand komen als men er niet voor zorgt dat deze deals op de gang bedenktermijn- proof zijn. Ik sta hierna nog uitvoerig stil bij dit aspect.

\section{Het verschil tussen de opzegging met instemming en de beëindigingsovereenkomst ten aanzien van de transitievergoeding}

Artikel 673 lid 1 bepaalt dat de werkgever aan de werknemer een transitievergoeding is verschuldigd indien de arbeidsovereenkomst ten minste 24 maanden heeft geduurd en de arbeidsovereenkomst door de werkgever is opgezegd. Zegt de werkgever op met instemming van de werknemer, dan is derhalve een transitievergoeding verschuldigd. Sluiten werkgever en werknemer een beëindigingsovereenkomst, dan is in beginsel geen transitievergoeding verschuldigd. Dit zou anders liggen indien de werkgever op grond van deze overeenkomst gehouden is tot opzegging van de arbeidsovereenkomst onder de aanvullende afspraak dat de werknemer daarmee instemt. Dit laatste is nu hoogst ongebruikelijk en zal ongetwijfeld ook na de inwerkingtreding van de Wwz geen praktijk worden. Er zit een enorm verschil tussen, kort gezegd, de deal die gepaard gaat met een opzegging met instemming van de werknemer en de deal die vastlegt dat de arbeidsovereenkomst tussen partijen met wederzijds goedvinden per een bepaalde datum tot een einde komt. Dat verschil ziet op de verplichting tot betaling van de transitievergoeding. Komen partijen tot een schriftelijke beëindigingsovereenkomst in de zin van artikel 670b lid 1, dan sluit - in de woorden van de memorie van antwoord de wettelijke regeling aan bij de partijautonomie. ${ }^{22}$ De wetgever heeft deze autonomie niet willen belasten met de verplichte transitievergoeding. De transitievergoeding zal natuurlijk een referentiewaarde vertegenwoordigen bij het treffen van een vertrekregeling, maar de wettelijke plicht tot het betalen van een bepaald bedrag geldt niet. De contractsvrijheid is een groot goed. De betreffende partijautonomie mogen wij inmiddels tot de grondrechten rekenen. ${ }^{23} \mathrm{Ik}$ ben evenwel

23 Het ging ook voor de inwerkingtreding van het Verdrag van Lissabon van 1 december 2009 reeds om een grondrecht, althans om een civielrechtelijk beginsel van een waarde die met die van een grondrecht vergelijkbaar is. Zie Asser/Hartkamp \& Sieburgh 6 III* 2010, nr. 59 en L.G. Verburg, Grondrechten in het arbeidsrecht, in: J.H. Gerards \& C.H. Sieburgh (red.), De invloed van fundamentele rechten op het materiële recht, Deventer: Kluwer 2013, p. 67-100, op p. 89-90. De contractsvrijheid is sedert 1 december 2009 een grondrecht via de band van de vrijheid van ondernemerschap als bedoeld in artikel 16 EU Handvest voor de grondrechten. Zie HvJ EU 18 juli 2013, C-426/11, JAR 2013/216, m.nt. Beltzer en NJ 2013/569, m.nt. Mok (Mark AlemoHerron e.a./Parkwood Leisure Ltd). 
bezorgd over de uitlegbaarheid van het onderscheid met de opzegging met instemming en ik vrees voor ongelukken en navenante juridisering.

Neem het voorbeeld van werkgever Jan die met zijn werknemer Kees in gesprek raakt over een uit elkaar gaan. Jan zegt tegen Kees dat hij de arbeidsovereenkomst wil opzeggen. Kees geeft aan dat hij daar anders over denkt. Jan zegt daarop tegen Kees dat hij bereid is 1000 euro op tafel te leggen als Kees bereid is in te stemmen. Kees zegt er een nachtje over te willen slapen. Ze spreken af dat Jan diezelfde middag nog de opzegging op papier zal zetten, inclusief de bereidheid 1000 euro te betalen bij instemming van Kees, en dat Kees Jan de volgende dag zal laten weten of hij akkoord gaat. Een dag later stapt Kees op Jan af en zegt hem dat hij akkoord gaat. Jan heeft nu de keus tussen (1) Kees schriftelijk diens instemming te laten bevestigen ${ }^{24}$ of (2) de deal vast te leggen in een door beide partijen te tekenen overeenkomst. In het eerste geval blijkt Jan later nog een transitievergoeding te moeten betalen (mits Kees er tijdig binnen drie maanden na de einddatum van het dienstverband achter komt dat deze vergoeding is verschuldigd ${ }^{25}$ ) en in beginsel zelfs gewoon bovenop de afgesproken 1000 euro. In het tweede geval is Jan geen transitievergoeding verschuldigd. Ik ging er in het voorbeeld van uit dat Jan en Kees geen van beiden het aspect van de transitievergoeding in de gaten hadden. Het kan ook zijn dat een van beiden wel wist van het belang van de precieze vormgeving van de deal, of er gaandeweg van op de hoogte raakte. Ik ben er niet zeker van dat betrokkene dit dan als een moeilijk dilemma zou beschouwen en treed maar niet in de vraag of men de ander al dan niet in onwetendheid zou laten. Beiden vallen onder het bereik van artikel 7:611 BW, maar niets menselijks is onze Jan en onze Kees vreemd. ${ }^{26}$ Kees kan nog gedurende drie weken de transactie ongedaan maken. Onbedoeld doet de bedenktermijn hier heilzaam normerend werk.

Ik geef nog een tweede voorbeeld. Werkgever Jan schrijft werknemer Kees dat hij het dienstverband wil opzeggen. Jan vraagt of Kees instemt als Jan 1000 euro op tafel legt. Kees schrijft terug er even over te hebben gedacht en in te stemmen als Jan bereid is de 1000 euro te verdubbelen tot 2000 euro. Jan schrijft terug dat dit akkoord is en dat dit betekent dat het dienstverband dan dus tot een einde komt per een door Jan precies genoemde einddatum (die overigens keurig klopt met de

24 De wettelijke voorwaarde van schriftelijkheid eist in mijn visie niet de ondertekening van één document. Aanbod en aanvaarding kunnen verspreid zijn neergelegd in twee of meer documenten. Wel moet men bij de eis van schriftelijkheid vasthouden aan de notie van rechtszekerheid en kenbaarheid. Deze meetlat wordt concreet gemaakt in artikel 6:227a BW. De eis van schriftelijkheid kwam meer algemeen aan de orde in mijn annotatie van HR 18 maart 2011, JAR 2011/108 (Monsieurs c.s./Wegener) in Het beding van artikel 7:613 BW: toepassingsgebied, de relatieve zwaarte van de '613'-maatstaf en het vereiste van schriftelijkheid, ArA 2012/1, p. 22-50, op p. 39-47. Zie ook A.E. Thijssen \& A.G.J.J. Jansen, Het concurrentiebeding: een papieren tijger of iets nieuws in de cloud?, ArbeidsRecht 2012/57. Beide artikelen bevatten verwijzingen naar verdere literatuur en jurisprudentie.

25 Gelet op de vervaltermijn van artikel 686a lid 4 onderdeel b.

26 Men zou hier kunnen denken aan de bestaande jurisprudentie over onderzoeksplichten c.q. informatieverplichtingen, maar het is de vraag hoe daarmee om te gaan. De vraag komt op of de norm van ' 611 ' dan ook niet wederzijdse verplichtingen in het leven roept. Ik laat het hier bij deze eerste aanzet tot verder nadenken. 
wettelijke termijn van opzegging) en betaling van twee mille. Hij vraagt Kees of ze er dan zo uit zijn. Kees reageert met: deal! Dit voorbeeld start met op de achtergrond een wettelijke verplichting tot betaling van een transitievergoeding en gaat aan het slot stilzwijgend over naar een arrangement waarbij geen transitievergoeding van toepassing is. Men kan dit waarderen als fijnzinnige juridische geleerdheid, maar ik vermoed dat het applaus in de praktijk slechts een beperkte omvang zal hebben. Ook in dit voorbeeld geldt weer dat de bedenktermijn (drie weken, want de werknemer is niet ingelicht over het bestaan van de bedenktermijn) nuttig werk kan doen om de 'misverstanden' te repareren, maar dat is dan meer toeval dan wijsheid. Uit de wetsgeschiedenis blijkt niet dat de bedenktermijn in de wet is opgenomen om het 'transactieverschil' tussen de opzegging met instemming en de beëindigingsovereenkomst recht te breien.

Wat is rechtens als Kees in het tweede voorbeeld in zijn laatste reactie niet kort 'deal!' schrijft, maar sober bericht dat hij in het voorstel van Jan berust? De Raad van State stelde in zijn advies de vraag wat 'berusten in' betekent en deed dit in het kader van de behandeling van de opzegging met instemming. ${ }^{27}$ De regering reageerde in het Nader Rapport met de bevestiging dat een schriftelijke instemming mede omvat de situatie waarin de werknemer het mogelijkerwijs niet helemaal eens is met het ontslag, maar hier toch mee instemt en er aldus in berust. ${ }^{28}$ Kan Kees nu met succes stellen dat hij heeft berust en dat dit overeenkomstig de wetsgeschiedenis gelijk staat met instemming met een opzegging en dat hij uit dien hoofde gerechtigd is tot een transitievergoeding? Als Jan pareert met de stelling dat het aanbod het aangaan van een beëindigingsovereenkomst betrof en niet het aangaan van een opzegging met instemming, kan Kees dan tegenwerpen dat in dit geval helemaal geen deal tot stand is gekomen, nu zijn aanvaarding betrekking had op een opzegging met instemming en niet op een beëindiging met wederzijds goedvinden? Het aanbod en de aanvaarding sloten derhalve niet op elkaar aan? Of zal de rechter met behulp van 'Haviltex' tot een uitleg komen van hetgeen is afgesproken? Men kan berusten in een opzegging, maar ik kan me goed voorstellen dat de aanduiding 'berusten in' ook valt uit te leggen als aanvaarding van een vertrekregeling van het type als bedoeld in artikel $670 \mathrm{~b}$ lid 1 . Het verstandige advies luidt waarschijnlijk: sluit geen deal zonder advies van een juridisch adviseur. Dat advies juridiseert het ontslagrecht echter wel. Dat laatste schijnt niet de intentie van de wetgever te zijn, maar die schijn bedriegt.

Waarschijnlijk meent de wetgever dat partijen steevast helderheid verschaffen over hetgeen zij willen afspreken. Wie iets langer aan de onderhandelingstafels heeft gezeten, weet beter. Veel advocaten zijn meesters in het buiten beeld houden van het achterste van de tong. In hun wereld gaat gezichtsverlies toch vooral over de kwaliteit van de pokerface. Sommige advocaten zijn zo goed van de tongriem gesneden dat zij niet eens weten waar dat achterste zit. Ik zou niet verbaasd staan als meer dan eens een werknemer na advies van een rechtsgeleerde adviseur een aan hem voorgelegde beëindigingsovereenkomst aan het slot nog wil (proberen te) wijzigen in een opzegging met instemming. Het zou veel beter zijn 
geweest als de wetgever de Wwz op het punt van chicanes had onderworpen aan een soort stresstest. De Wwz begeeft zich nu eenmaal op een terrein dat rechtvaardigheid zoekt, maar ook veel emoties oproept en middelen laat zien die het onderste uit de kan tot doel hebben.

\section{De bedenktermijn en de bestuurder}

In een voordracht tijdens het VAAN-congres van 17 januari 2014 heb ik de wetgever opgeroepen de bedenktermijn na het sluiten van een beëindigingsovereenkomst voor de bestuurder te laten vallen. De notie van ongelijkheidscompensatie ligt hier in mijn visie wat anders dan bij de gewone werknemer. Bij een vertrekregeling op bestuursniveau spelen de belangen van het bedrijf een belangrijkere rol. Ik gaf in mijn pleidooi aan dat in ieder geval voor de beursgenoteerde bestuurders met een dienstverband een bedenktermijn niet zou passen. ${ }^{29}$ Deze personen doppen vrij aardig de eigen bonen, maar bovendien geldt dat een beursvennootschap een exitregeling op dit functieniveau als koersgevoelige informatie direct openbaar moet maken. Ik schrok van de gedachte dat de vennootschap het risico zou lopen een week of twee later in de pers te moeten mededelen dat de bestuurder zich had bedacht en de met hem getroffen deal had ontbonden. De media zouden natuurlijk smullen, maar het leek me niet aantrekkelijk voor het bedrijf, ook niet prettig voor de mogelijkerwijs direct al aangekondigde opvolger en zeker niet goed voor de beurswaarde. Nederland zou internationaal bezien ogen als een republiek waarin men vooral in bananen doet. Dit betoog vond gehoor bij de fractie van D66. Naar aanleiding van vragen van deze partij ontnam de wetgever aan de bestuurder de bedenktermijn. ${ }^{30}$ Daarbij werd gekozen voor een ruimhartige definitie van het begrip bestuurder. Het resultaat is te vinden in artikel 670 b lid 5. De regeling van de bedenktermijn is niet van toepassing op de bestuurder van een rechtspersoon indien herstel van de arbeidsovereenkomst op grond van Boek 2 BW niet mogelijk is, ${ }^{31}$ noch op een bestuurder van een vergelijkbare buitenlandse rechtspersoon. ${ }^{32,33}$

29 Het speelt slechts in de gevallen waarin het beursfonds en de bestuurder de suggestie van de wetgever hebben gevolgd om de bestuurder in dienst te laten treden bij een dochtervennootschap om te ontkomen aan de eis van artikel 2:132 lid 3 BW. Zie over deze 'suggestie' Kamerstukken I 2010/11, 31763, C, p. 12.

30 Kamerstukken II 2013/14, 33818, 7, p. 57.

31 Ik noteer dat de bestuurder van een stichting vooralsnog buiten deze uitzonderingsbepaling valt. Boek 2 BW bevat immers geen regeling van de positie van de stichtingsbestuurder. De stichtingsbestuurder beschikt dus vanaf 1 juli 2015 wel over het recht van de bedenktermijn, tenzij tegen die tijd de stichtingsbestuurder een met de bestuurders van de andere rechtspersonen vergelijkbare plek in Boek 2 BW heeft gevonden.

32 Deze laatste uitzondering is in lijn met het oordeel van de Hoge Raad in HR 15 september 1995, NJ 1996/234 (Bennenbroek/Scia). Scia Group N.V. betrof een vennootschap naar Belgisch recht.

33 Kamerstukken II 2013/14, 33818, 7, p. 57/58 en Kamerstukken II 2013/14, 33818, 8, p. 17. 


\section{De bedenktermijn en 'de deal op de gang': de formele ontbinding en de overeenkomst over de 'losse eindjes' in de MvT}

Ik heb op 17 januari 2014 - op een wijze die de Engelsen met een tongue in cheek aanduiden - een 'oplossing' aangedragen voor het toen nog bestaande probleem van deals met bestuurders die door de bedenktermijn zouden worden geraakt: de terugkeer van de formele ontbindingenpraktijk. ${ }^{34}$ Wie kiest voor een formele ontbinding in combinatie met een overeenkomst over de met het einde verband houdende 'secundaire zaken', ontloopt de bedenktermijn. De ontbinding bewerkstelligt namelijk het einde van de arbeidsovereenkomst en niet de deal zelf. De deal stelt dat men de rechter samen verzoekt de arbeidsovereenkomst te ontbinden. Deze aanpak is, zo stelde ik op 17 januari 2014, bedenktermijn- proof. Die stelling vloeide voort uit de hiervoor reeds kort besproken tekst van bladzijde 103 van de MvT: 'Als een arbeidsovereenkomst wordt beëindigd na een ten overstaan van de rechter getroffen schikking - het spreekwoordelijke "de gang op gestuurd worden" met rechterlijke aanwijzingen - zal het einde van de arbeidsovereenkomst doorgaans in de rechterlijke uitspraak zijn belichaamd (de ontbinding) en wordt hooguit nog een beëindigingsovereenkomst gesloten voor de "losse eindjes" (vakantiegeld, vakantiedagen, bonus, kwijting, e.d.). Op een dergelijke beëindigingsovereenkomst is deze bepaling [betreffende de bedenktermijn; LV] niet van toepassing, en dus evenmin de veertien-dagen-termijn, omdat hier geen sprake is van een overeenkomst die de arbeidsovereenkomst doet eindigen.' 35

De hier geciteerde tekst van bladzijde 103 van de MvT vormde een niet te missen 'uitnodiging' om de praktijk van formele ontbindingen nieuw leven in te blazen. De tekst is, zoals al verwoord, ondanks de al vermelde kanttekeningen van Sagel, overeind gebleven in het wetgevingsproces en staat dus nog steeds 'als een huis'. Op deze constatering past slechts één uitzondering: in de memorie van antwoord van 1 mei 2014 treft men de aanvullende stelling dat de rechter enkel over kan gaan tot ontbinding na de deal op de gang 'wanneer naar zijn oordeel sprake is van een redelijke grond voor ontslag. ${ }^{36}$ Ik kom later nog terug op deze uitlating. Het belang van de tekst van bladzijde 103 van de MvT is enorm en was dat bij het schrijven van de MvT ook al voor de wetgever zelf. De wetgever wilde met de geciteerde tekst voorkomen dat de bedenktermijn in ontbindingszaken ter zitting

34 De act bestond in de hoogtijdagen uit zittingen bij de kantonrechter die pakweg 5 minuten duurden en tot doel hadden te bewerkstelligen dat er een ontbindingsbeschikking kwam die de arbeidsovereenkomst op een tussen partijen afgesproken datum ontbond op een wijze die de WW-toets der kritiek doorstond. Advocaat-stagiairs brachten zo een deel van hun tijd reizend en in de gerechtsgebouwen door. Later werd het mogelijk formele ontbindingen schriftelijk af te doen. De wijziging van de WW van 1 oktober 2006 bracht een zodanige beperking van de verwijtbaarheidstoets in de WW dat eindelijk dit voor arbeidsrechtelijk Nederland vrij trieste hoofdstuk uit de geschiedenis (in de eerste plaats een product van de preventieve toetsing van ontslagen) op een redelijk aanvaardbare wijze kon worden afgesloten. Het heeft de advocatuur gesierd dat men dit afscheid van de formele ontbinding con amore heeft omarmd, hoewel voor nogal wat arbeidsrechtelijk gespecialiseerde advocaten de praktijk van formele ontbindingen tot dan toe een relevante bron van inkomsten was. 
getroffen schikkingen in de wielen zou gaan rijden. Het is van algemene bekendheid dat de mondelinge behandeling van een ontbindingsverzoek een prachtige gelegenheid biedt ontslagkwesties alsnog te regelen. Rechters handelen er naar. Ik bedoel daar ook mee dat zij met gepaste distantie en overredingskracht partijen in de richting van een schikking bewegen. Het moment speelt een voorname rol. De kans op succes (dat wil zeggen: de kans dat men tot een deal komt) is veel groter als partijen op dat moment in het gerechtsgebouw tot zaken komen. De kans op succes is veel geringer als de rechter de mondelinge behandeling (of de beschikking) een paar weken aanhoudt om de partijen daarmee de gelegenheid te bieden er alsnog zelf uit te komen. Het is ongetwijfeld waar dat een dergelijke pressure cooker de kans op het bereiken van een deal aanmerkelijk vergroot, maar het is ook de perceptie van alle betrokkenen dat het waar is. Deze perceptie is dagelijkse realiteit. Rechters weten dit alles net zo goed als (en soms beter dan) de advocaten, begrijpen de psychologische aspecten en dynamiek, en veel rechters beheersen het spel van het zo mogelijk binnenboord halen van een verdere kosten en risico's besparend compromis. Zo werkt het al jaren en het werkt, zou ik menen, goed. Het is van groot maatschappelijk belang dat deze mogelijkheid blijft bestaan. De wetgever heeft de geschetste aanpak met recht niet in de waagschaal willen stellen door de bedenktermijn roet in dit eten te laten gooien. De deal op de gang moest, met andere woorden, worden gered van de vernietigende werking van de bedenktermijn. De geciteerde tekst van bladzijde 103 van de MvT toont het reddingsplan. Dit plan is inderdaad sluitend. Er zit evenwel een bijsluiter bij en die bijsluiter geeft onder het kopje 'bijwerkingen' onmiskenbaar aan dat het reddingsplan ook werkt voor ontbindingen in zaken waarin partijen al eerder de weg naar een deal hebben gevonden. Deze bijsluiter had de wetgever naar ik vermoed niet helder op het netvlies staan, nu de formele ontbinding vroeger een WW-doel diende, terwijl het nut van een formele ontbinding hier tot doel heeft de periode van de bedenktermijn terug te brengen van veertien dagen tot een paar dagen (ik vermoed dat door de bank genomen twee werkdagen goed werkbaar is, maar het kan sneller als het moet).

De deal op de gang vormt het sluitstuk van een traject dat voert tot een vertrekregeling. Het doet er voor de deal op de gang niet toe hoe dit traject verliep. Een ontbindingsverzoek kan van meet af aan onderdeel zijn geweest van een door partijen samen bedacht plan van aanpak, maar het is ook mogelijk dat partijen na indiening van het (inhoudelijke) verzoekschrift of na ontvangst van het (inhoudelijke) verweerschrift al nader tot elkaar kwamen. Veel deals komen kort voor de mondelinge behandeling tot stand. In de laatste uren en minuten voor de zitting loopt de spanning altijd op en druk maakt ingenomen posities vloeibaar. Dit is ook een van de redenen dat zoveel zaken uiteindelijk toch nog 'op de gang' worden geschikt. Vaak moet eerst stoom worden afgeblazen of heeft men een duwtje in de rug nodig. In dergelijke kwesties zal inderdaad pas na de pleidooien 'op de gang' een regeling tot stand komen. Het hoeft zo niet te gaan. Elk schikkingstraject ziet er weer anders uit.

Wat de MvT op bladzijde 103 stelt, komt in het geval dat partijen zelf al op enig moment voorafgaand aan de mondelinge behandeling een 'plan van aanpak' afstemden, neer op het volgende: de werkgever dient een ontbindingsverzoek in, 
de werknemer komt met een verweerschrift, partijen worden uitgenodigd voor een mondelinge behandeling, de ontbindingsrechter stuurt partijen ergens tijdens de zitting de gang op met een paar zinnen die de betrokkenen herkennen als een rechterlijke aanwijzing, een minuut of wat later komen partijen alweer terug en berichten de rechter op een wijze die men herkent als een ten overstaan van de rechter getroffen schikking, waarna de rechter ontbindt en de partijen de meegebrachte schriftelijke verwoording van de afspraken betreffende de 'losse eindjes' tekenen (de 'losse eindjes'-overeenkomst, de LEO) en huiswaarts keren. Op deze LEO is de wettelijke bepaling betreffende de bedenktermijn niet van toepassing, en dus evenmin de 14-dagentermijn, omdat hier geen sprake is van een overeenkomst die de arbeidsovereenkomst doet eindigen. De MvT bevestigt dit met zoveel woorden. De dag na de zitting ontvangen de partijen de ontbindingsbeschikking. ${ }^{37}$ De zitting zelf zal al met al, zelfs als het op de gang sturen letterlijk wordt genomen en niet slechts een virtuele exercitie betreft, niet meer dan vijf minuten nemen. Zo staat het allemaal voorgekookt en beschreven op bladzijde 103 van de MvT. ${ }^{38}$ Ik taxeer dat het in de toekomst mogelijk zal zijn een en ander in een digitale omgeving in een handomdraai (of beter: enige klikken van de muis) tot een goed einde te brengen.

Bij nota van wijziging is in artikel $670 \mathrm{~b}$ opgenomen dat de beëindigingsovereenkomst schriftelijk moet worden aangegaan. Deze eis van schriftelijkheid geldt niet voor de LEO. In het wetgevingsproces is aan dit aspect terecht geen verdere aandacht geschonken. Het antwoord op de vraag of de LEO schriftelijk moet zijn aangegaan, is al in de MvT gegeven met de constatering dat de overeenkomst

37 De einddatum wordt bepaald met inachtneming van het bepaalde in artikel 671b lid 8. De structuur van de deal dient daar rekening mee te houden. Kiezen partijen voor een andere einddatum (dan overeenstemt met artikel 671b lid 8), dan kan dat uiteraard op zich wel. Het is echter de vraag of de rechter in een ontbindingsbeschikking hier in mee kan gaan. Ik denk dat het dwingendrechtelijke karakter van de wettelijke regeling een beletstel vormt. Zie ik dat juist, dan zullen partijen niettemin aan de gekozen einddatum kunnen vasthouden, maar dan als een einde met wederzijds goedvinden. Daarmee vervalt dus de in de tekst besproken ontbinding als hulpmiddel om de bedenktermijn te 'bekorten'. De rechter kan wel steeds op verzoek van partijen met het oog op het aan de werknemer verschaffen van een executoriale titel de afgesproken ontslagvergoeding in de ontbindingsbeschikking opnemen zonder acht te hoeven slaan op de wettelijke regelingen van de transitievergoeding en de billijke vergoeding. De wettelijke regeling van de transitievergoeding is niet van toepassing en de deal staat er uiteraard aan in de weg dat men aan de wettelijke regeling van de billijke vergoeding toekomt. Het is niet nodig om in een pro-formaontbindingsprocedure een ernstige verwijtbaarheid van de werkgever te 'construeren' om de ontbindingsrechter bevoegd te maken een hogere vergoeding toe te kennen dan overeen zou stemmen met de transitievergoeding. De bevoegdheid van de rechter om in een pro-forma-ontbinding de afgesproken vergoeding op te nemen, valt terug te voeren op de regeling van artikel 686a lid 3. De tussen partijen afgesproken ontslagvergoeding is, minst genomen, een in artikel 686a lid 3 bedoelde, met de ontbinding verband houdende andere vordering.

38 Ik sloot op 17 januari 2014 mijn betoog af met de 'lichtvoetige' suggestie dat we in arbeidsrechtelijk Nederland een soort '48-uurs service' voor formele ontbindingen zouden moeten organiseren en ik dacht daar bij te kunnen helpen door met de VAAN te komen tot de oprichting van een arbitrage-instituut. Ik heb eerder over zo'n instituut nagedacht in De ontbindingsrechter en het CWI gepasseerd: arbitrage als the third way van het ontslagrecht, in: R. Hansma (red.), De ontbinding van de arbeidsovereenkomst in tienvoud, Reeks Vereniging voor Arbeidsrecht nr. 35, Deventer: Kluwer 2005, p. 149-162. 
betreffende de 'losse eindjes' de arbeidsovereenkomst niet doet eindigen. Het betreft derhalve geen overeenkomst als bedoeld in artikel 670b. Ook dit is een belangrijke opmerking. Indien partijen daadwerkelijk eerst op de gang schikken, hebben ze waarschijnlijk niet al een pasklare schriftelijke overeenkomst ter tekening bij de hand. Dat vormt geen beletsel voor een finale regeling, nu mondelinge afspraken volstaan. Overigens zal de rechter in dergelijke gevallen in beginsel bereid zijn de belangrijkste afspraken van de schikking op te laten tekenen en op te nemen in of als bijlage te voegen bij het proces-verbaal van de zitting. Dit voorkomt dat later blijkt dat partijen elkaar toch niet helemaal goed hebben verstaan. Een wettelijke voorwaarde is het schriftelijke karakter echter niet.

\section{De bedenktermijn en 'de deal op de gang': de formele ontbinding en de overeenkomst over de 'losse eindjes' revisited}

Hoe reageerde de regering op de suggestie dat de in de Wwz opgenomen bedenktermijn mogelijk de weg wijst naar een nieuw tijdperk van pro-formaontbindingen? Het antwoord laat zich raden: afwerend. In de nota naar aanleiding van het verslag van 3 februari 2014 stelde de regering dat de rechter slechts kan ontbinden als daarvoor een redelijke grond bestaat. Een ontbinding kan bovendien niet worden gestoeld op een bedrijfseconomische grond (de agrond), nu bij een ontslag wegens bedrijfseconomische redenen slechts het UWV bevoegd is. Daarnaast overwoog de regering dat de overeenstemming van partijen over het willen beëindigen door pro-forma-ontbinding door de rechter op zichzelf ook in een beëindigingsovereenkomst zal zijn neergelegd. In dat geval hebben partijen immers overeenstemming. Ten overvloede merkte de regering hierbij nog op dat in de huidige praktijk de pro-forma-ontbinding leidt tot een beschikking die in beginsel niet appellabel is. In het nieuwe recht is dat anders. Ook hieruit volgde naar de mening van de regering dat het aangaan van een pro-formaontbinding niet de wellicht door partijen beoogde tijdwinst en definitieve zekerheid zou opleveren. ${ }^{39}$

De regering behandelde het thema opnieuw in het schriftelijk debat met de Eerste Kamer in reactie op opmerkingen in de notitie betreffende wetsvoorstel 33818 door de VAAN. In de memorie van antwoord (MvA) leest men de bevestiging dat indien in een deal afgesproken is dat de arbeidsovereenkomst eindigt door een pro-forma-ontbinding, met betrekking tot deze overeenstemming geldt dat een bedenktermijn van toepassing is. Is de ontbinding al binnen deze termijn uitgesproken, dan geldt dat de arbeidsovereenkomst inmiddels is geëindigd door ontbinding, zodat van een herroeping van de instemming of ontbinding van de beëindigingsovereenkomst op grond van de bedenktermijn geen sprake meer kan zijn en overigens zulks ook niet het daaraan gekoppelde effect zou kunnen sorteren. Deze situatie zou in de visie van de MvA evenwel in de praktijk niet snel spelen, nu de rechter moet beoordelen of er sprake is van een redelijke grond voor ontslag. Gelet op het hiermee gemoeide tijdsverloop zou volgens de regering de 
bedenktermijn veelal al voor de datum van ontbinding van de arbeidsovereenkomst zijn verstreken. ${ }^{40}$ Vervolgens ging de regering in op de deal op de gang tijdens een mondelinge behandeling van een ontbindingsverzoek. In deze situatie kwam, aldus de regering, het einde van de arbeidsovereenkomst in de rechterlijke uitspraak tot uitdrukking. Een rechter zou hiertoe enkel over kunnen gaan wanneer naar zijn oordeel sprake is van een redelijke grond voor ontslag. De arbeidsovereenkomst is in dit geval geëindigd door middel van ontbinding, volgend op een daartoe door een van de partijen gedaan verzoek. Over de mogelijkheid van hoger beroep wilde de regering ten overvloede aangeven dat - anders dan nu het geval is - de rechter niet de laatste rechterlijke instantie is die zich over een ontbinding kan uitspreken en aldus niet kan worden uitgesloten dat een der partijen ook na een pro-forma-ontbindingsbeschikking deze mogelijkheid zou willen benutten. Gelet op het feit dat de rechter enkel de arbeidsovereenkomst kan ontbinden bij de aanwezigheid van een redelijke grond voor ontslag, en hoger beroep en cassatie daartegen openstaan, bestond voor een verzoek om pro-formaontbinding naar de mening van de regering dan ook geen aanleiding. De regering was ook geen voorstander van pro-formaprocedures vanwege de onnodige belasting van de rechterlijke macht die hiermee gepaard zou gaan.

Hoe te denken over deze reactie van de regering? Het valt op dat de regering een aantal malen wijst op de eis dat de kantonrechter slechts kan ontbinden als daarvoor een redelijke grond bestaat. In de MvA voegt de regering eraan toe dat gelet op het tijdsverloop dat met de beoordeling van de bewuste grond is gemoeid, de bedenktermijn veelal al voor de datum van ontbinding van de arbeidsovereenkomst is verstreken. De regering is hier zichtbaar het spoor bijster. Het is aan de rechter om te bepalen of er een redelijke grond is voor ontbinding. Het is ook aan de rechter om te bepalen hoeveel tijd dat neemt. Niets belet de rechter in een geschikte kwestie mede af te gaan op het gezamenlijk oordeel van partijen dat de verhoudingen zijn verstoord (de g-grond). Ook de 'vangnetbepaling' van artikel 669 lid 3 onderdeel h zal dienst kunnen doen. In de wetsgeschiedenis heeft de regering het voorbeeld gegeven van de voetbaltrainer die in de visie van de voetbalclub moet vertrekken. Dit kan onder meer een gevolg zijn van verschillen van inzicht over het te voeren beleid. In de visie van de regering is de h-grond in zo'n situatie bruikbaar. ${ }^{41}$ Welnu, verschillen van inzicht over het te voeren beleid spelen niet alleen in de voetbalwereld. Niets belet de rechter om acht te slaan op het gezamenlijke standpunt van partijen dat zij inderdaad op niet te repareren wijze van inzicht verschillen over het te voeren beleid. Sterker nog, het ligt bepaald in

40 Kamerstukken I 2013/14, 33818, C, p. 88.

41 Kamerstukken II 2013/14, 33818, 7, p. 130. De h-grond kan niet worden gebruikt voor het 'repareren' van een onvoldoende onderbouwing van een ontslag waarvoor geen redelijke grond bestaat zoals opgenomen onder de overige onderdelen van artikel 669 lid 3. Het is mijn stellige indruk dat het debat over het werkelijke nut van de h-grond in de wetsgeschiedenis is vertroebeld door de vrees van de regering dat de h-grond zou worden ingezet als verzachter van de andere gronden. Dat heeft de regering niet gewild. Een verschil van inzicht over het te voeren beleid valt niet onder de overige gronden. Daarom is de h-grond geschikt om dergelijke kwesties te 'ontvangen'. Het voorbeeld van de voetbaltrainer toont dit aan. Hetzelfde geldt bijvoorbeeld voor de materie van de botsende karakters. 
de rede dat de rechter daar wel ernstig rekening mee houdt. Het kan spelen in geschikte zaken, maar ook aan de orde zijn in niet-geschikte zaken. Ik laat nog in het midden dat als dit te pas zou komen, partijen in een geschikte zaak zo kunnen opereren dat het lijkt alsof men geen regeling heeft kunnen bereiken (de praktijk van de formele ontbindingen uit het verleden heeft ons, naar van algemene bekendheid mag zijn, ook dat soort varianten gebracht). Natuurlijk zal de aangevoerde grond, zoals de MvA aangeeft, overigens wel binnen het speelveld van de ontbindingsrechter (de gronden c tot en met h van artikel 669 lid 3) moeten liggen.

Ik ga nog een stap verder. In de MvT maakt de regering een uitzondering (van de werking van de bedenktermijn) voor de deal op de gang. In de MvA vult de regering aan met de gedachte dat een rechter na een deal op de gang enkel over kan gaan tot ontbinding wanneer naar zijn oordeel sprake is van een redelijke grond voor ontslag. Ook stelt de MvA dat met het oordeel over de redelijke grond een zeker tijdsverloop gemoeid zal zijn en wel zodanig dat de bedenktermijn veelal al voor de datum van ontbinding van de arbeidsovereenkomst zal zijn verstreken. Dat wil zeggen: zo'n oordeel neemt een paar weken! Dat valt niet met elkaar te rijmen. Een verstandige ontbindingsrechter vormt zich natuurlijk voorafgaande aan een mondelinge behandeling al een zeker voorlopig oordeel over de kwestie op basis van de inhoud van het ontvangen verzoekschrift en verweerschrift en de bijlagen bij deze processtukken. De rechter kan natuurlijk niet zijn definitieve oordeel over de redelijkheid van de grond al hebben bepaald voordat ter zitting partijen en hun raadslieden aan het woord zijn geweest. Anders zou sprake zijn van vooringenomenheid. Dat mag (absoluut) niet. Vervolgens zal de rechter partijen de gang op sturen met (eventueel) wat aanwijzingen. Terwijl de partijen op de gang onderhandelen heeft de rechter wat minuten, een kwartier, mogelijk zelfs een halfuur of nog iets langer, om de redelijkheid van de grond nader te beoordelen. Hij kan moeilijk bij terugkeer van de partijen in de rechtszaal (die net na moeizaam overleg tot een deal zijn gekomen) aan deze partijen en hun raadslieden voorhouden dat hij helaas nog niet tot een oordeel over de redelijkheid van de grond heeft kunnen komen, althans niet zonder hoog te scoren op de jaarlijkse top tien van meest idiote uitspraken.

De rechter zal zijn voorlopig oordeel al gereed hebben voordat hij partijen de gang op stuurt. Anders wordt het ook lastig om aanwijzingen te geven. In ieder geval zal de rechter het oordeel dat sprake is van een redelijke grond hebben bereikt op het moment dat partijen tot een deal op de gang zijn gekomen en hem daarover berichten.

Over het bedoelde tijdsverloop valt nog te zeggen dat inderdaad goed denkbaar is dat de rechter, zich mede verlatend op het gezamenlijke oordeel van partijen, in luttele minuten tot de conclusie komt dat sprake is van een redelijke grond. Dat is veel minder dan de paar weken die de regering in de MvA blijkbaar in voorkomend geval voor zo'n oordeel uittrekt. Rechters zijn ervaren beslissers, het is hun vak. Men dient zich overigens te bedenken dat veel beslissingen niet beter worden door er langer over na te denken. De financiering van de rechtspraak in ons land loopt bovendien compleet vast indien de regering inderdaad van rechters zou vergen dat men over zoiets als een oordeel over een redelijke grond een 
paar weken doet. Zonder onderzoek te hebben gedaan durf ik de stelling aan dat de financiering van de rechterlijke macht zo is vormgegeven dat rechters veel meer tempo in het doorhakken van knopen aan de dag (moeten) leggen dan de MvA lijkt te veronderstellen. De toegenomen werkdruk van de kantonrechter is de laatste jaren een gekend gespreksonderwerp geworden. Ik denk niet dat rechters zich redelijkerwijs kunnen permitteren tijd besparende deals te torpederen zonder dat daar een werkelijk goede grond voor is.

Nog weer een ander chapiter is dat veel deals op de gang tot stand komen en zullen komen in ontslagkwesties waarin de rechter welbeschouwd waarschijnlijk helemaal niet tot ontbinding over zal (willen) gaan. De Wwz zal door het lastiger maken van ontslagen (het vaster worden van vaste dienstverbanden kwam hiervoor al ter sprake) het aandeel van dergelijke gevallen nog laten stijgen. Nemen wij de MvA al te letterlijk, dan mag in dit soort gevallen de rechter partijen niet meer de gang op sturen. Dat zou een stevige toename van het aantal geschillen opleveren en een navenante verzwaring van de belasting van de rechterlijke macht tot gevolg hebben. Ik geloof om deze en andere redenen niet dat het die kant uit moet gaan. Wij kunnen de curieuze tekst van de MvA een passende plek geven door het ervoor te houden dat voldoende is dat de rechter alsnog van de redelijkheid van de grond overtuigd kan raken door (het laatste zetje van) het gezamenlijk oordeel van partijen dat de relatie op de aangevoerde grond tot een einde moet komen. Het is niet nodig dat deze overtuiging bij de rechter reeds heeft postgevat op het moment dat partijen de gang op gaan. Het is voldoende dat de rechter overtuigd is als op het moment dat bij terugkeer van de partijen in de rechtszaal blijkt dat de zaak is geschikt. U ziet, het nieuwe ontslagrecht wordt een stuk eenvoudiger.

De regering wijst tot slot nog op het feit dat de Wwz voorziet in hoger beroep en cassatie van ontbindingsbeschikkingen. In de woorden van de MvA kan niet worden uitgesloten dat een der partijen ook na een pro-forma-ontbindingsbeschikking deze mogelijkheid zou willen benutten. Dat is juist. Het kan, maar ik vermoed dat niet veel raadslieden een cliënt adviseren een pad op te gaan dat het karakter heeft van een doodlopende weg. Ik denk aan het aloude adagium point d'interet, point d'action. Ik ga er ten minste van uit dat partijen een finale kwijting overeenkwamen. De finale kwijting zal state of the art verwoorden dat partijen ter zake van het dienstverband en het einde daarvan niets meer van elkaar te vorderen hebben en elkaar finale kwijting verlenen. Deze finale kwijting maakt onderdeel uit van de 'losse eindjes', en in het vorenstaande is gebleken dat de desbetreffende overeenkomst (de LEO) stand houdt op dezelfde wijze als geldt voor andere wederkerige overeenkomsten. De LEO valt buiten het bereik van de bedenktermijn. Men kan wel van een formele ontbindingsbeschikking in beroep gaan, maar de hoven kunnen voor de verzoeker in dat hoger beroep niets betekenen. Een hoger beroep stuit af op de kwijtingsclausule die niet wordt geraakt door het thema van de bedenktermijn. Dit geldt dan behoudens de uitzonderlijke situatie dat de LEO zelf aantastbaar is op de gronden die het verbintenissenrecht aanreikt (wilsgebreken enzovoort). Ik kan me wel voorstellen dat het verstandig is dat partijen in de losse eindjes nog afspreken dat zij over en weer afzien van hoger 
beroep van de te geven ontbindingsbeschikking (ook zo'n typisch los eindje) en ten overvloede de finale kwijting nog oprekken tot het dienstverband dat zou ontstaan als een hof in beroep toch zou oordelen dat herstel (artikel 683 lid 3) geraden is. U ziet, het ontslagrecht wordt niet alleen een stuk eenvoudiger, maar ook minder complex.

Zou op enig moment in de toekomst de wetgever de rechterlijke macht hier toch onvoldoende speelruimte bieden, dan is er natuurlijk de mogelijkheid uit te wijken naar bindend advies of arbitrage. Deze wijze van geschillenbeslechting is door de regering expliciet in de wetsgeschiedenis bevestigd. ${ }^{42}$

\section{De bedenktermijn en de deal die tijdens de ontbindingsprocedure tot stand komt}

Een laatste punt betreft de vraag hoe om te gaan met deals die ergens tijdens de ontbindingsprocedure tot stand komen. De regering gaat in de wetsgeschiedenis 'zwart-wit' uit van inhoudelijk gevoerde ontbindingsprocedures en formele ontbindingen, maar op elk moment kan een inhoudelijke ontbindingsprocedure veranderen in een geschikte zaak. Indien partijen bijvoorbeeld een schriftelijke beëindigingsovereenkomst aangaan binnen een termijn van twee weken vóór de mondelinge behandeling van een al inhoudelijk gestarte ontbindingsprocedure, zou de zitting toch inhoudelijk doorgang moeten vinden om geen tijd te verliezen als de werknemer nadien de bedenktermijn gebruikt en de deal ontbindt. De toezegging geen gebruik te maken van de bedenktermijn baat niet. Deze toezegging is nietig (artikel 670b lid 6). Het is in het belang van beide partijen hier een mouw aan te passen, omdat de werknemer die met zijn werkgever een (gunstige) deal kan treffen wat verbouwereerd zou staan te kijken als zijn advocaat hem uitlegt dat hij toch de kosten die zijn verbonden aan het opstellen van een verweerschrift en het voorbereiden van het pleidooi moet maken om de werknemer tegen zichzelf en zijn eigen toekomstige daden in bescherming te nemen.

Wat te doen als bijvoorbeeld de dag voor de mondelinge behandeling de geesten toch rijp zijn geworden en een schikking binnen handbereik ligt? Hierboven heb ik de weg gewezen van een plan van aanpak en het voorbereiden van een LEO, waarna de rechter ter zitting het verzoek krijgt partijen naar de gang te sturen. De werkgever, zijn advocaat en de advocaat van de werknemer zullen zich niettemin op een inhoudelijke zitting moeten (blijven) voorbereiden, nu de werknemer altijd tot op de zitting (c.q. tot op de gang) de bedenktermijn kan gebruiken en kan

42 Kamerstukken I 2013/14, 33818, C, p. 111, Kamerstukken I 2013/14, 33818, E, p. 15/16. Het laatstgenoemde Kamerstuk verwoordt dat arbitrage en bindend advies steeds mogelijk zijn, derhalve ook voor de aan het UWV overgelaten beslissing of er een grond voor opzegging is. Arbitrage en bindend advies staan dus aan de praktijk ter beschikking als alternatief voor de rol van het UWV als bedoeld in artikel 671a lid 1, als alternatief voor dan wel samenvallend met de onafhankelijke commissie als bedoeld in artikel 671a lid 2, en als alternatief voor de ontbindingsrechter. Partijen kunnen in de regeling van de arbitrage of het bindend advies hoger beroep uitsluiten. Men kan de afspraak vooraf in de arbeidsovereenkomst treffen of op het moment van het ontstaan van het geschil. 
overgaan tot ontbinding van de deal. Denkbaar is dat rechters in dit soort situaties de datum van de mondelinge behandeling kunnen vervroegen. Ook de gerechten hebben belang bij medewerking, al was het maar omdat zij anders met meer inhoudelijke zittingen (en uren leeswerk vooraf!) worden belast dan nodig is. Ik denk dat de gerechten zullen verkennen of het, afhankelijk van de aanvoer van geschikte zaken, zin heeft een speciale rechter (eventueel bij toerbeurt) aan te wijzen die de op verzoek van partijen vervroegde geschikte ontbindingszaken afwikkelt. Mogelijk zal het allemaal niet zo'n vaart lopen. In veel kwesties zal de druk van het moeten opstellen van inhoudelijke processtukken een passende invloed hebben op het onderhandelingsproces. Ik bedoel hiermee dat partijen zullen proberen te bewerkstelligen dat er zo veel mogelijk duidelijkheid is over de kans van slagen van een schikking op een moment dat twee weken ligt voor de datum waarop men aan de slag moet met een processtuk of met de voorbereiding van de zitting. Denk bijvoorbeeld aan het tekenen van een schriftelijke beëindigingsovereenkomst twee weken voor het moment dat de werknemersadvocaat anders het verweerschrift moet gaan opstellen. Er is bovendien nog een alternatieve oplossing. Deze oplossing komt in de volgende paragraaf ter sprake en vloeit voort uit de introductie van de antistapelingsbepaling in de nota van wijziging van 3 februari 2014.

\section{De antistapelingsbepaling en de deal bij wijze van tweetrapsraket}

Tot de nota van wijziging van 3 februari 2014 lag het thema van de bedenktermijn (nog) zwaarder op de maag dan nu het geval lijkt te zijn. Ik schrijf dit met enige voorzichtigheid, nu het vermoeden gerechtvaardigd is dat het bedrijfsleven nog niet is doordrongen van de precieze werking van de bedenktermijn in een werkomgeving als die van de Wwz. Ik noem twee redenen voor de gedachte dat de formele ontbinding uiteindelijk wellicht geen al te forse comeback hoeft te maken.

Ik doel in de eerste plaats op het al gememoreerde feit dat de 'bestuurder' buiten het bereik van de bedenktermijn is gebracht. De wens om direct en onomkeerbaar tot zaken te komen en niet het risico te lopen dat veertien dagen later blijkt dat er alsnog geen regeling is, speelt steevast bij de allerhoogste functies en voorts vooral bij sensitieve posities, in gevallen waarin de werkgever bereid is een forse kop op de transitievergoeding te zetten tegenover directe zekerheid ('boter bij de vis'-gevallen) en in ontslagkwesties waarin de verhoudingen compleet zijn verstoord geraakt (al eerder of juist - zoals vaker gebeurt - als gevolg van de soms emotierijke onderhandelingen rondom de exit). De bestuurders zaten als doelgroep in de eerste koets en die koets heeft de wetgever bij nota van wijziging buiten het speelveld geplaatst. In veel ontslaggevallen zal geen onoverkomelijk bezwaar hoeven te bestaan tegen een 'wachttijd' van veertien dagen en al helemaal niet in die kwesties waarin de werknemer na een ontbinding van de deal nog 'gewoon' werkzaamheden kan verrichten zonder dat de organisatie direct op tilt gaat. Speelt dit laatste wel, dan is het oppassen geblazen en zal een verstandige werkgever de betrokken werknemer niet eerder van het verrichten van werk- 
zaamheden vrijstellen dan nadat de bedenktermijn ongebruikt is verstreken. Een lastig met elkaar nog twee weken in al dan niet in aangepaste vorm arbeidend blijven verkeren is altijd te verkiezen boven een ongewilde terugkeer na een ontbonden deal. ${ }^{43}$

In de tweede plaats heb ik het oog op het effect van de antistapelingsbepaling. Deze bepaling maakt een andere uitweg mogelijk. Het willens en wetens construeren van een werknemersopzegging louter omwille van het omzeilen van de bedenktermijn is in de visie van de wetgever niet te verenigen met de plichten rustend op een werkgever op grond van artikel 7:611 BW. ${ }^{44}$ Dit pad is derhalve in beginsel niet begaanbaar. Dat lijkt mij juist. Geldt deze vingerwijzing van de wetgever ook voor het construeren van het inroepen van de bedenktermijn? Ik doel op wat ik de tweetrapsraket noem. Het gaat bij deze raket om de vrijblijvende afspraak tussen de raadslieden van werkgever en werknemer dat deze partijen een vertrekregeling aangaan, een desbetreffende schriftelijke vaststellingsovereenkomst ondertekenen (de eerste trap van de raket), die vervolgens een dag of wat later (eerst een enkel 'nachtje slapen') door de werknemer in een schriftelijke verklaring wordt ontbonden, waarna partijen opnieuw een (tweede) al dan niet gemodificeerde schriftelijke vaststellingsovereenkomst aangaan en ondertekenen (de tweede trap van de raket). De hier bedoelde afspraak is niet bedoeld afdwingbaar te zijn, heeft zoals gezegd een vrijblijvend karakter. Het kan ook niet anders. Elk beding dat het bedenkrecht uitsluit of beperkt is nietig. Maar als het daadwerkelijk zo loopt, lijkt mij in beginsel sprake te zijn van een aanpak die de toets der kritiek kan doorstaan. Het gaat niet om een uitsluiting of beperking van de bedenktermijn. Het is aan de werknemer om te bepalen of hij zijn recht gebruikt. Als hij dat recht gebruikt, doet hij in feite wat de wetgever voor ogen stond. Nergens is opgetekend dat van de bedenktermijn pas na verloop van tijd gebruik mag worden gemaakt. Artikel 670b lid 2 spreekt over 'binnen veertien dagen' en kent geen minimumperiode van beraad. Denkbaar is dat de regering de tweetrapsraket niet op het netvlies had bij het introduceren van de antistapelingsbepaling. De wetsgeschiedenis geeft geen duidelijkheid over enige raadpleging van de praktijk. Het doet er ook niet toe. De wet verbiedt een beding dat beperkt, maar verbiedt geen aanpak die gebruikmaakt van de mogelijkheden die de wet biedt. Natuurlijk moet de praktijk er zorg voor dragen dat misbruik van de tweetrapsraket geen

43 Indien u meent dat bij verstoorde verhoudingen in het geval van een ontbonden deal de werknemer toch zelf ook niet graag zal willen terugkeren (op zich juist) en het dus met een terugkeer waarschijnlijk geen vaart zal lopen (in beginsel onjuist), loopt u nog niet zo lang in de arbeidsrechtelijke praktijk mee. Veel adviseurs raden werknemers aan dan juist weer aan de slag te gaan. De intentie zal niet zijn dit lang te willen volhouden. Dat lukt ook zelden (het thema is dan ook nauw verwant aan dat van de situatieve arbeidsongeschiktheid). De intentie is vrijwel steeds de prijs van de (tweede) deal op te drijven. Vandaar mijn suggestie in de tekst om na het tekenen van een deal gedurende de looptijd van de periode van de bedenktermijn niet tot een nonactiviteit over te gaan (en dit dus ook niet in de deal zelf af te spreken). Ik durf de stelling wel aan dat bij een non-activiteit tijdens de looptijd van de bedenktermijn er een grotere kans is op het door de werknemer ontbinden van de deal dan bij een moeten doorwerken - al dan niet in aangepaste vorm - gedurende deze periode van twee weken. 
voet aan de grond krijgt. Zonder 'nachtje slapen' kan ik me goed voorstellen dat de rechter een deal die wordt aangegaan, direct daarna wordt ontbonden, waarna wederom tot ondertekening wordt overgegaan (en dat alles binnen een zeer kort tijdsbestek), zal duiden als een 'knipperlichtdeal' en oordeelt dat zo bekeken sprake is van een beperking van het recht. De knipperlichtdeal wordt in mijn visie getroffen door de in artikel $670 \mathrm{~b}$ lid 6 bedoelde nietigheid. ${ }^{45} \mathrm{Ik}$ acht het voorts van belang dat de werknemer bij toepassing van de tweetrapsraket wordt bijgestaan door een raadsman naar eigen keuze. Treft men daags voor de mondelinge behandeling van een inhoudelijke ontbindingsprocedure een deal, dan acht ik de gang naar de kantonrechter en een deal op de gang met een direct te tekenen LEO een juistere aanpak. De rechter zal het daarbij op prijs stellen dat de partijen hem wel zo spoedig mogelijk laten weten dat voorstelbaar is dat de zitting minder tijd zal nemen (deze enkele mededeling zonder enige verdere uitwijding volstaat natuurlijk om de rechter te zeggen dat het er alle schijn van heeft dat de bekende gang witte rook zal verschaffen). Dat voorkomt onnodig urenlang lezen in stukken die een dag later alleen maar achtergrondmuziek zullen blijken te zijn van de redelijkheid van de maatgevende grond.

Ik vermoed dat de wijze waarop de praktijk met de bedenktermijn zal omgaan, in een van de toegezegde evaluaties van de Wwz in de komende jaren een passende plaats zal krijgen. Ook om die reden is het verstandig met een dergelijke 'tweetrapsraket', hoe vrijblijvend ook, niet te scherp aan de wind te varen.

\section{Concluderend}

Ik treed in deze bijdrage niet in de vraag of de bedenktermijn een bestaand probleem oplost dan wel toch vooral nieuwe problemen op tafel legt. Hoewel in vogelvlucht bekeken geen sprake is van een aanmerkelijk bestaand maatschappelijk probleem en de rechtspraak al wel wat rugdekking aan de werknemer biedt, ${ }^{46}$ zijn er op individueel niveau ongetwijfeld zaken te vinden waarvan men achteraf kan zeggen dat de werknemer baat zou hebben gehad bij het bestaan van een bedenkrecht. Zeker is dat de regeling van de bedenktermijn in de Wwz het treffen van deals belast. Het inroepen van de bedenktermijn bewerkstelligt een buiten-

45 De beëindigingsovereenkomst is een vaststellingsovereenkomst en een vaststelling ter beëindiging van onzekerheid of geschil als bedoeld in artikel 7:902 BW. Dat geldt evenwel niet voor een beding dat de bedenktermijn beoogt om zeep te brengen. Een dergelijk beding wordt in artikel $670 \mathrm{~b}$ lid 6 niet alleen nietig geoordeeld, maar zou ook de strekking hebben om in strijd met dwingend recht te handelen. Dat geeft niet slechts strijd met dwingend recht, maar levert ook strijd op met de openbare orde. Voor een dergelijke vaststellingsovereenkomst verleent artikel 7:902 BW geen rugdekking. Loonstra en ik schreven eerder in soortgelijke zin over de in artikel 7:902 BW geboden mogelijkheid in een vaststellingsovereenkomst rondom het einde van de arbeidsovereenkomst af te wijken van dwingend recht. Zie C.J. Loonstra \& L.G. Verburg, Hoe exclusief is exclusief? Over de juridische status van de 685-procedure en de contractuele vergoeding, ArA 2005/1, p. 48-75. Een recent voorbeeld van een overeenkomst die geen rugdekking krijgt van artikel 7:902 BW is te vinden in Ktr. Utrecht 2 mei 2014, JAR 2014/152.

46 Zie wat Sagel daarover schreef in zijn eerder in de tekst besproken bijdrage over de bedenktermijn in de TRA van maart 2014. Het thema is de regering niet ontgaan. Zie Kamerstukken II 2013/14, 33818, 3, p. 27. 
gerechtelijke vernietiging van het resultaat van de overeenstemming. De wetgever heeft evenwel gesproken en het is nu zaak ons voor te bereiden op de dingen die komen gaan. Daar hoort de bedenktermijn bij. De grote invloed die dit nieuwe fenomeen heeft op het schikken van ontslagzaken en het feit dat de wetsgeschiedenis zichtbaar heeft geworsteld met het thema (en niet helemaal boven is gekomen), brachten mij tot deze bijdrage.

De Wwz maakt een niet goed uitlegbaar onderscheid tussen de beëindigingsovereenkomst en de opzegging met instemming op het punt van de verplichting van de werkgever tot betaling van een transitievergoeding. Ik acht dit ongelukkig en vrees ook voor ongelukken. Het bij ontslagzaken aansturen op een regeling van het vertrek met wederzijds goedvinden wordt meer nog dan voorheen een zaak voor juristen. Dat juridiseert het ontslagrecht. De regering heeft in de wetsgeschiedenis opgetekend dat men streefde naar een minder complex ontslagrecht met een geringere mate van juridisering. De nieuw gefabriceerde bouwsteen van de bedenktermijn bereikt het tegenovergestelde. Dat is eens te meer spijtig nu voor de arbeidsrechtelijke praktijk het beredderen van deals dagelijkse arbeid vormt.

Wij zullen de terugkeer zien van de pro-forma-ontbinding van de arbeidsovereenkomst, niet meer voor WW-doeleinden, maar met het oog op het bekorten van de periode van de bedenktermijn. Dit speelt bij alle ontslagzaken die zich slecht lenen voor een bedenktermijn van veertien dagen. Ik denk aan ontslagen van werknemers op hoge en/of sensitieve posities, gevallen waarin de werkgever bereid is een forse kop op de transitievergoeding te zetten tegenover directe zekerheid ('boter bij de vis'-gevallen) en aan ontslagkwesties waarin de verhoudingen compleet verstoord zijn geraakt. De nieuwe pro-formapraktijk dient de weg te volgen die de MvT wijst op bladzijde 103, met inachtneming van de kanttekeningen die daarbij in het vorenstaande zijn geplaatst.

Er is een alternatief voor de formele ontbinding. Deze 'derde weg' maakt gebruik van de antistapelingsbepaling en draagt er zorg voor dat de werknemer na het tekenen van de deal ruim binnen de termijn van veertien dagen gebruikmaakt van zijn bedenkrecht en vervolgens opnieuw een deal treft (de tweetrapsraket). Het wegcontracteren van de bedenktermijn is nietig. Aan een vaststellingsovereenkomst die de bedenktermijn beperkt, verleent artikel 7:902 BW geen rugdekking. De crux zit bij de tweetrapsraket in de gedachte van het gebruik van de bedenktermijn. Dat mag natuurlijk wel, mits uit vrije wil. Die wil mag in mijn visie in voorkomend geval vrijblijvend wat worden bijgestuurd. Ik denk dat die bijsturing met het oog op het gevraagde niveau van vrijblijvendheid toch vooral dient te komen van de kant van de eigen raadsman van de werknemer. Bovendien zal tussen de eerste en de tweede trap zoveel denkruimte moeten zitten dat de werknemer daadwerkelijk uit vrije wil besloot de tweede trap in werking te stellen. In zoverre is aan de aanduiding 'vrijblijvend' in het kader van de bedenktermijn eerst recht gedaan als bij het betreden van de tweede trap de vrije wil juist gericht was op het niet blijven. 